\title{
FARMERS EMPOWERMENT ON FOOD SECURITY PROGRAM IN ENGGAL MAJU FARMERS GROUP ASSOCIATION OF KEBUMEN REGENCY
}

\author{
Ahmad Muhtarom ${ }^{1}$, Teguh Djuharyanto ${ }^{2}$ and Adhi Iman Sulaiman ${ }^{3}$ \\ ${ }^{1}$ Agribusiness Master Program, Graduate School, Universitas Jenderal Soedirman, \\ Purwokerto, Central Java, Indonesia \\ ${ }^{2}$ Agriculture Faculty, Universitas Jenderal Soedirman, Purwokerto, \\ Central Java, Indonesia \\ ${ }^{3}$ Faculty of Social and Political Sciences, Universitas Jenderal Soedirman, \\ Fakultas Ilmu Sosial dan Ilmu Politik \\ Correspondence Email: muhtarom21@gmail.com
}

Submitted 03 July 2020; Accepted 17 Desember 2020

\begin{abstract}
ABSTRAK
Pertanian merupakan sektor strategis dalam pembangunan nasional karena berperan penting dalam pemenuhan pangan dan terwujudnya ketahanan pangan. Sikap petani merupakan salah satu aspek penentu keterlibatan petani dalam program pemberdayaan ketahanan pangan. Penelitian bertujuan menganalisis sikap petani dan faktor yang mempengaruhinya pada program pemberdayaan ketahanan pangan. Menggunakan mixed method, jumlah responden penelitian adalah 60 petani anggota Gapoktan Enggal Maju Kabupaten Kebumen yang ditentukan secara cluster sampling dan untuk data kualitatif informan dipilih secara purposive. Sikap petani dianalisis secara deskriptif dan faktor yang yang mempengaruhinya menggunakan analisis regresi linier berganda. Hasil penelitian menyatakan bahwa sikap petani ditinjau dari komponen kognitif, afektif dan konatif pada tujuan, sasaran, pelaksanaan dan manfaat kegiatan tergolong sangat tinggi. Umur petani, luas lahan garapan, pengalaman pribadi, pendidikan formal, pendidikan non formal dan pengaruh orang lain yang dianggap penting secara bersama-sama berpengaruh nyata terhadap sikap petani. Secara parsial luas lahan garapan, pengalaman pribadi dan pengaruh orang lain yang dianggap penting berpengaruh nyata terhadap sikap petani dalam program pemberdayaan ketahanan pangan. Perlunya memaksimalkan fungsi kelompok tani, konsistensi penyuluh, dinas dan ketua Gapoktan mendampingi dan membimbing petani sehingga keberlanjutan kegiatan tetap terjaga.
\end{abstract}

Kata kunci: distribusi, gapoktan, pangan, pemberdayaan, sikap

\begin{abstract}
Agriculture is a strategic sector in national development because it plays an important role in food availability and realizes food security. The Farmer's attitude is one of the determining aspects to involvement farmers in empowerment programs for food security. A research, aiming to describe the farmer's attitude and analyze the farmer's attitudes and the influence factors that influence the farmer's attitudes on the food security empowerment program. The research used mixed method, the number of research respondents was 60 farmers members of the farmer's group association Enggal Maju Kebumen District, determined by cluster random sampling, and for qualitative data, the informants were selected purposively. The Farmer's attitude analyzed with descriptive analysis and the influence factors of farmers' attitude used multiple linear regression analysis. Farmer's attitude analyzed with descriptive analysis and the influence factors of farmer's attitude used multiple linear regression analysis. The result show that the farmer's attitudes in terms of cognitive, affective, and conative components toward the objectives program were high, farmer's attitudes towards, the target, implementation, and benefits of the program were very highly classified. Farm size, personal experience, and the influence of the
\end{abstract}


important people were a significant effect on the farmer's attitudes in food security empowerment programs. The need to maximize the function of farmer's groups, consistency of extension workers, agencies and heads of Gapoktan assist and guide farmers so that the sustainability of activities is maintained.

Keywords: distribution, farmer's group association, food, empowerment, attitude

\section{INTRODUCTION}

Agriculture is one of the key sectors for Indonesia's development, where agriculture is the livelihood of the most population. In 2019, the number of people working in the agricultural sector was 34,58 million $(27,33 \%)$ of the 126,51 million Indonesian population. Agriculture is the largest sector that absorbs labor in addition to the other two key sectors, namely the trade sector $(18,81 \%)$ and processing industry $(14,96 \%)$ (Central Bureau of Statistics, 2019a). In addition, population growth leads to increased food needs. In 2019, the Indonesian population projection data was 268,07 million, and if it is multiplied by the stipulated annual per capita of rice consumption of 111,58 kilograms, then the demand for rice in 2019 was 29,91 million tons (Central Bureau of Statistics, 2018a, 2018b). The data shows a large amount because when calculated from the Indonesia total rice production in 2019 of 31,31 million tons, it is equivalent to $96 \%$ of the total rice production for that year (Central Bureau of Statistics, 2019b).

The fulfillment of food as a basic human need is related to the concept of food security which includes three pillars, namely the food availability, food access, and food utilization. Efforts to achieve food security in the pillar of food access still have obstacles such as limited availability of farmers in obtaining financing or assistance for their farming activities. Another problem is the fluctuation of the resulting commodity prices. According to the Food Security Agency (2015) and Sriati et al (2016), the problem of price fluctuations for unhulled rice and rice during the harvest season and famine season as well as farmers' access to farming are the problems faced by farmers, especially in food crop commodities.

One of the approaches to addressing problems in the pillar of food access both institutionally and to farmers is through empowerment. According to Mustangin et al (2017) that in the development process, community involvement can be done by using the empowerment approach. Empowerment is an effort to raise awareness and community involvement in development to achieve an improved quality of life physically, mentally, socially, economically, culturally, and become independent (Mardikanto and Soebianto, 2017). In 2009, the Food Security Agency of the Ministry of Agriculture implemented an empowerment program for Farmers Group Association (Gapoktan) which is engaged in food distribution and reserves through the Strengthening of Community Food Distribution Institutions (P-LDPM) activities and in 2016 through Community Food Business Development (PUPM).

Enggal Maju Farmers Group Association (Gapoktan) is one of the recipients of the food security empowerment program from the Ministry of Agriculture through the Strengthening of Community Food Distribution Institutions (P-LDPM) activities in 2011 and Community Food Business Development (PUPM) activities in 2017. In 2011, there were 26 Farmers Group Association (Gapoktan) recipients of the Strengthening of Community Food Distribution Institutions (P-LDPM) activities in Central Java Province, which is spread across 22 regencies and there were 71 Farmers Group Association (Gapoktan) recipients of Community Food Business Development (PUPM) activities in 2017, which is spread across 29 regencies. Farmers Group Association (Gapoktan) activities are carried out through distribution activities and rice reserves. 
Enggal Maju Farmers Group Association (Gapoktan) won first place for 2018 Adhikarya Pangan Nusantara award in Central Java Province. However, there are still some obstacles in the activities of $\mathrm{P}$ LDPM and PUPM including not all farmers who are members of Enggal Maju Farmers Group Association (Gapoktan) have sold their unhulled rice to Gapoktan, obstacle to the transfer of knowledge from Gapoktan to farmers, Gapoktan partnerships are carried out between farmers and other parties outside the Gapoktan area, but they need to pay attention to the patterns of cooperation, and Gapoktan has good leadership but they need to pay attention to leadership dominance factors.

The success of P-LDPM and PUPM activities are closely related to the responses or attitudes of the farmers. Attitudes according to contemporary social psychologists are categorized through two approaches including (1) attitudes as a form of a combination of reactions to knowledge, feelings, behavioral tendencies towards an object, and (2) attitudes are limited only to aspects of affection in the form of positive or negative assessments of the object of attitude (Azwar, 2009). The attitude of farmers who are open and willing to accept ideas or change ideas affects the success of an activity. This was stated by Simanjuntak et al (2016) that attitudes have a strong influence on the involvement of farmers in the Association of Implementation of Rice Integrated Crop Management program (GPP-TTP). Azwar et al (2016) also stated that the positive attitude of farmers towards an activity had an impact on high levels of participation. This study is different from previous research because it is conducted on the Farmers Group Association (Gapoktan) which carried out two activities including P-LDPM and PUPM and based on the three components of attitude, namely knowledge/cognitive, feeling/affective, and behavioral/conative tendencies.

Based on the previous explanation, $\mathrm{P}$ LDPM and PUPM activities provide benefits if farmers are actively involved and one of them is influenced by the positive attitude of the farmers towards the activities. P-LDPM and PUPM activities that are well implemented and the achievements of Enggal Maju Farmers Group Association (Gapoktan) in the field of food security are interesting to study. The objective of this study was to analyze the attitudes of farmers and the factors that influence them on the activities of P-LDPM and PUPM in Enggal Maju Farmers Group Association (Gapoktan), Kebumen Regency, Central Java Province.

\section{RESEARCH METHODS}

This study uses the mixed-methods sequential explanatory, namely quantitative data analysis and supported by qualitative data (Creswell, 2018). The study was conducted at Enggal Maju Farmers Group Association (Gapoktan), Tanjungsari Village, Kutowinangun Sub-district, Kebumen Regency, Central Java Province. The population in this study was all farmers of members of Enggal Maju Farmers Group Association as many as 147 farmers. The sampling using probability sampling techniques with cluster sampling. The informants on qualitative data were selected purposively. According to Siregar (2015), the determination of the sample unit was conducted purposively because it was based on certain criteria. The number of samples taken using the Slovin formula at an error tolerance of $10 \%(0,1)$. Thus, the number of samples was 60 respondents.

Primary data are attitudes and the influencing factors which are conducted by distributing questionnaires, in-depth interviews, and observations. Secondary data are the P-LDPM and PUPM activities which in this study obtained from publications and data from the Ministry of Agriculture, the Department of Agriculture and Food Security of Kebumen Regency, the Central Bureau of Statistics, the Agricultural Extension Center of Kutowinangun Sub-district, Tanjungsari Village Government, books, and previous research journals. Quantitative data were 
collected using questionnaires that have been tested for validity and reliability at Farmers Group Association (Gapoktan) that receive the same activity, namely Gapoktan Karya Maju, Majatengah Village, Kemangkon Subdistrict, Purbalingga Regency. Measurement of farmer attitudes using a Likert scale. Qualitative data were collected through interviews with informants involved in PLDPM and PUPM activities including the Head of farmer groups, the Head of the Farmers Group Association (Gapoktan), farmers, extension agents, and the Department of Agriculture and Food Security of Kebumen Regency. The validity testing of qualitative data using the triangulation method, namely source triangulation, technique triangulation, and time triangulation.

Qualitative data analysis was conducted by reducing data, presenting data, and concluding data (Miles et al, 2014). Quantitative data analysis was carried out descriptively and inferentially. The descriptive analysis intends to explain the description of research respondents and farmer attitudes. Farmers' attitudes were analyzed by calculating the maximum score, minimum score, median, quantile 1 , and quantile 3. Based on these scores are then categorized into four categories, namely very low attitude, low attitude, high attitude, and very high attitude.

The inferential analysis intends to determine the factors that influence farmer attitudes and use multiple linear regression analysis. Questionnaire data were transformed from ordinal data into interval data using the Method of Successive Interval (Sarwono, 2012). The next stage is the classical assumption test which includes the normality test, multicollinearity test, heteroscedasticity test, and linearity test. Multiple linear regression analysis to determine the factors that influence farmer attitudes using SPSS.25 software with the following regression model.

$$
\begin{gathered}
\mathrm{Y}=\mathrm{a}+\mathrm{b} 1 \times 1+\mathrm{b} 2 \times 2+\mathrm{b} 3 \times 3+\mathrm{b} 4 \times 4+\mathrm{b} 5 \times 5+ \\
\mathrm{b} 6 \times 6+\mathrm{e}
\end{gathered}
$$

Information:

$\mathrm{Y}=$ Attitude

a $\quad=$ Constant

b1-b6 = Coefficient

$\mathrm{X} 1=$ Farmers age

$\mathrm{X} 2=$ Land area

$\mathrm{X} 3=$ Personal experience

$\mathrm{X} 4=$ Formal education

$\mathrm{X} 5=$ Non formal education

X6 $=$ The influence of others who are considered important

e $\quad=$ Error.

The research hypothesis testing was conducted with the $\mathrm{F}$ test to determine the effect simultaneously and the t-test to determine the partial effect (Ghozali, 2018). The coefficient of determination was conducted to determine the magnitude of the contribution of the factors that influence attitudes towards farmers attitudes.

\section{RESULTS AND DISCUSSION}

\section{Description of Farmer of the Members of Enggal Maju Farmers Group Association}

The results showed that on average farmer was of productive age. Productive age population is the population aged between 1564 years (Central Bureau of Statistics of Central Java Province, 2018b). The number of farmers of productive age is 56 farmers $(93 \%)$ and farmers of non-productive age are 4 $(7 \%)$. Nevertheless, the majority of farmers as many as 43 people $(71,66 \%)$ aged between 46-64 years or in the elderly category. This is due to the lack of interest of young people in the agricultural sector, the perception that agriculture is not economically promising, and choose to work in other sectors. In 2019, the number of Indonesian young people was 64,19 million, and those who work in the agricultural sector are only 11,83 million $(18,43 \%)$, the remaining 16,92 million $(26,37 \%)$ work in the manufacturing sector, and 35,43 million $(55,20 \%)$ work in the service sector (Central Bureau of Statistics, 2019c). 
Table 1. Respondent Characteristics

\begin{tabular}{|c|c|c|c|c|c|}
\hline No & Information & Indicator & Category & Total & Percentage \\
\hline \multirow[t]{6}{*}{1} & \multirow[t]{6}{*}{ Age } & \multirow{6}{*}{$\begin{array}{l}\text { Age of farmer members of } \\
\text { Gapoktan }\end{array}$} & Seniors $(\geq 65$ year $)$ & 4 & 6,66 \\
\hline & & & Elderly (46-64 year) & 43 & 71,66 \\
\hline & & & Late adult ( $36-45$ year) & 9 & 15,00 \\
\hline & & & Early adult (26-35 year) & 3 & 5,00 \\
\hline & & & Late teens ( $15-25$ year) & 1 & 1,66 \\
\hline & & & Early teens (12-14 year) & 0 & 0 \\
\hline \multirow[t]{5}{*}{2} & \multirow[t]{5}{*}{ Land area } & \multirow{5}{*}{$\begin{array}{l}\text { Area of land cultivated by } \\
\text { farmers per growing season } \\
\text { (hectares) }\end{array}$} & Very wide ( $>2$ hectare) & 0 & 0 \\
\hline & & & Wide (1-2 hectare) & 7 & 11,70 \\
\hline & & & Intermediate $(0,51-1$ hectare $)$ & 8 & 13,30 \\
\hline & & & Narrow $(0,25-0,5$ hectare $)$ & 8 & 13,30 \\
\hline & & & Very narrow $(<0,25$ hectare $)$ & 37 & 61,70 \\
\hline \multirow[t]{12}{*}{3} & \multirow{12}{*}{$\begin{array}{l}\text { Personal } \\
\text { experience }\end{array}$} & Length of farming & $>10$ year & 55 & 91,70 \\
\hline & & \multirow[t]{2}{*}{ experience } & 6-10 year & 2 & 3,30 \\
\hline & & & $1-5$ year & 3 & 5,00 \\
\hline & & \multirow{5}{*}{$\begin{array}{l}\text { Length of participation in } \\
\text { the group }\end{array}$} & $>5$ year & 38 & 63,30 \\
\hline & & & 4 year & 10 & 16,70 \\
\hline & & & 3 year & 6 & 10,00 \\
\hline & & & 2 year & 5 & 8,30 \\
\hline & & & $<1$ year & 1 & 1,70 \\
\hline & & \multirow{4}{*}{$\begin{array}{l}\text { Activeness in group } \\
\text { activities (one last planting } \\
\text { season) }\end{array}$} & Always ( $>6$ times) & 6 & 10,00 \\
\hline & & & Often (3-6 times) & 24 & 40,00 \\
\hline & & & Seldom (1-2 times) & 27 & 45,00 \\
\hline & & & Never & 3 & 5,00 \\
\hline \multirow[t]{5}{*}{4} & \multirow{5}{*}{ Formal education } & \multirow{5}{*}{ The last education taken } & D3/Bachelor & 0 & 0 \\
\hline & & & Senior High School & 7 & 11,67 \\
\hline & & & Junior High School & 15 & 25,00 \\
\hline & & & Elementary School & 34 & 56,67 \\
\hline & & & $\begin{array}{l}\text { Not completed in elementary } \\
\text { school }\end{array}$ & 4 & 6,67 \\
\hline \multirow[t]{8}{*}{5} & \multirow{8}{*}{$\begin{array}{l}\text { Non formal } \\
\text { education }\end{array}$} & \multirow{8}{*}{$\begin{array}{l}\text { Extension and mentoring } \\
\text { activities that were } \\
\text { followed (one last planting } \\
\text { season) } \\
\text { Training activities followed } \\
\text { (one last growing season) }\end{array}$} & Always ( $>6$ times) & 3 & 5,00 \\
\hline & & & Often (3-6 times) & 10 & 16,70 \\
\hline & & & Seldom (1-2 times) & 46 & 76,70 \\
\hline & & & Never & 1 & 1,70 \\
\hline & & & Always ( $>6$ times) & 1 & 1,70 \\
\hline & & & Often (3-6 times) & 10 & 16,70 \\
\hline & & & Seldom (1-2 times) & 41 & 68,30 \\
\hline & & & Never & 8 & 13,30 \\
\hline \multirow[t]{16}{*}{6} & \multirow{16}{*}{$\begin{array}{l}\text { The influence of } \\
\text { others who are } \\
\text { considered } \\
\text { important }\end{array}$} & \multirow{4}{*}{$\begin{array}{l}\text { The role of the extension } \\
\text { officer in outreach and } \\
\text { mentoring activities }\end{array}$} & $\begin{array}{l}\text { Planning-implementation- } \\
\text { monitoring and evaluation }\end{array}$ & 29 & 48,30 \\
\hline & & & Planning-implementation & 8 & 13,30 \\
\hline & & & Planning & 11 & 18,30 \\
\hline & & & Not accompanying & 12 & 20,00 \\
\hline & & $\begin{array}{l}\text { The role of the extension } \\
\text { officer in training activities }\end{array}$ & $\begin{array}{l}\text { Planning-implementation- } \\
\text { monitoring and evaluation }\end{array}$ & 31 & 51,70 \\
\hline & & & Planning-implementation & 12 & 20,00 \\
\hline & & & Planning & 5 & 8,30 \\
\hline & & & Not accompanying & 12 & 20,00 \\
\hline & & $\begin{array}{l}\text { The role of the chairman of } \\
\text { Gapoktan }\end{array}$ & $\begin{array}{l}\text { Planning-implementation- } \\
\text { monitoring and evaluation }\end{array}$ & 18 & 30,00 \\
\hline & & & Planning-implementation & 16 & 26,70 \\
\hline & & & Planning & 18 & 30,00 \\
\hline & & & Not accompanying & 8 & 13,30 \\
\hline & & $\begin{array}{l}\text { Role of related government } \\
\text { agencies }\end{array}$ & $\begin{array}{l}\text { Planning-implementation- } \\
\text { monitoring and evaluation } \\
\text { Planning-implementation }\end{array}$ & 28 & 46,70 \\
\hline & & & Planning & 21 & 35,00 \\
\hline & & & Not accompanying & 4 & 6,70 \\
\hline & & & & 7 & 11,70 \\
\hline
\end{tabular}




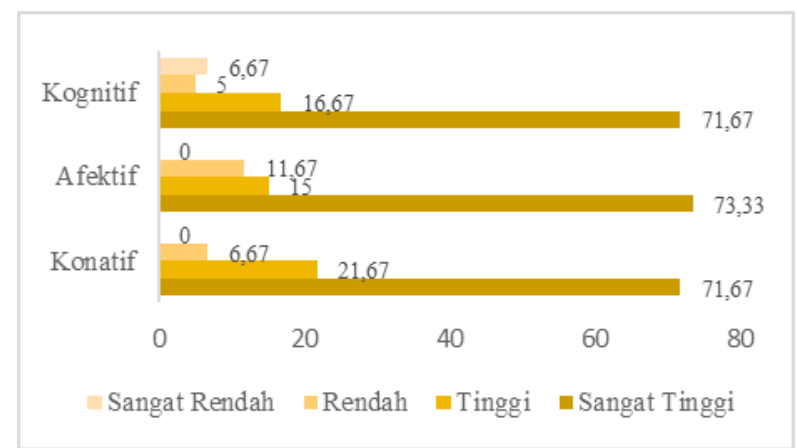

Figure 1. Attitude of Farmers on Objectives (Source: Primary Data, 2020)

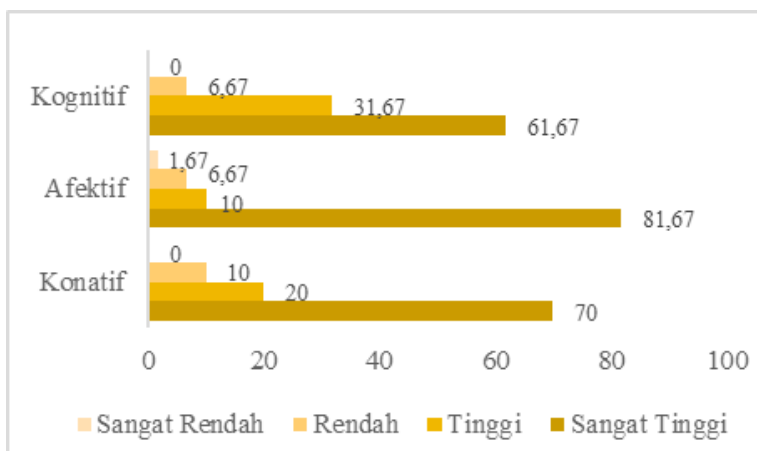

Rendah $=$ Rendah $\square$ Tingi $\square$ Sangat Tinggi

Figure 3. Attitude of Farmers on Implement (Source: Primary Data, 2020)

The aging population of farmers also affects the productivity of their farming businesses because they tend to find it difficult to accept innovation and change.

The analysis showed that as many as 37 farmers $(61,7 \%)$ have a very narrow land area (less than $0.25 \mathrm{ha}$ ). The number of agricultural business households that control land under 0,5 ha in Kebumen Regency is $213.836(89,37 \%)$, land tenure from 0,5 - 0,99 ha is $20.222(8,45 \%)$ and the rest is 5.222 $(2.18 \%)$ are land tenure of 1 ha or more (Central Bureau of Statistics of Central Java Province, 2018a).

Farmers generally have been in farming for more than 10 years and have participated in groups over 5 years. The longer the farming they run, the more experienced they are in dealing with or solving problems. According to Ikhsan (2018) that farmers with longer farming activities have better knowledge, abilities, and experience and therefore affecting their decision-making. Purnama (2017) also revealed that personal experiences such as

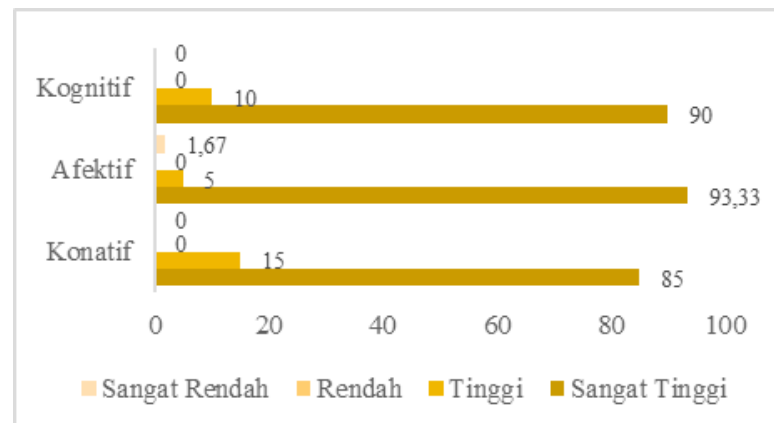

Figure 2. Attitude of Farmers on Target (Source: Primary Data, 2020)

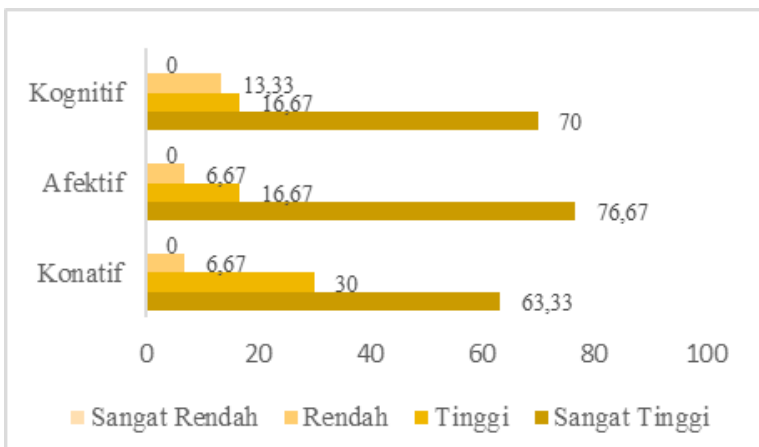

Sangat Rendah $\backsim$ Rendah $\backsim$ Tinggi $\quad$ Sangat Tinggi

4. Attitude of Farmers on Benefits (Source: Primary Data, 2020)

length of farming, involvement in groups, cultivation activities are important factors in shaping farmers' attitudes in making partnerships with buyer companies.

The average level of education of the research respondents is primary education. The low level of education of farmers is influenced by the younger generation who are very selective in choosing jobs in their villages according to their level of education (Susilowati, 2016). Hamyana (2017) also stated that there are economic, social, and environmental motives for the young generation in the village in choosing a job, and they prefer to work outside agriculture because they considered it more profitable to meet their daily needs.

Farmers rarely participate in extension, mentoring, and training activities. This is due to several things, namely (1) they have another agenda when the activities are held, (2) they only invite Gapoktan representatives and farmer groups at certain times, (3) farmers are less concerned about routine events and they feel more enthusiastic 
when the events are providing assistance programs, and (4) limited budget so that not all Farmers Group Association (Gapoktan) members are invited. According to Alif (2017) extension and training activities have several obstacles including a lack of information about the material to be provided, the timing of the event was not right, the material presented was not interesting, and no reward for attending the meetings. In fact, the presence of farmers is important in the extension process.

Research respondents stated that the role of the extension agent, the Department of Agriculture and Food Security of Kebumen Regency, and the Head of Farmers Group Association (Gapoktan) were at all stages of the activity. The role of the Department of Agriculture and Food Security is to decide Gapoktan recipient, conduct education, implementation of activities, mentoring, monitoring, and evaluation of activities. The extension agent as a mentor or representative who is appointed by the agency to assist at each stage of the activity. The Head of Farmers Group Association (Gapoktan) is the coordinator of the management and the four farmer groups are under him. The Head of Gapoktan also plays a role in coordinating and communicating with related parties outside of Gapoktan, opening and developing partnerships with the same business actors.

\section{Farmers' Attitudes in Food Security Empowerment Activities}

Farmers' attitudes towards the objective of the activity in terms of the cognitive component were classified as very high as many as 43 farmers $(71,67 \%)$, the affective component was very high as many as 44 farmers $(73,33 \%)$, and the conative component was classified as very high as many as 43 farmers $(71,67 \%)$. This shows that the farmers' knowledge of the P-LDPM and PUPM activities is good. Farmers know and agree on the objectives of Farmers Group Association (Gapoktan) activities is one of the efforts to overcome farmers' problems, especially during the post-harvest time.
Farmers have a very high attitude to be involved in activities because if the objectives of the activity are implemented properly, it will help farmers in selling their crops. The very high attitude of farmers towards the objectives of the activity, among others, is realized in their involvement in meetings for planning Gapoktan activities at the beginning of the planting season. The meeting was held in order to agree on rice farming activities such as planning the planting time, tractor use, labor wages, irrigation, harvest costs, post-harvest costs, and costs of using Gapoktan food reserves.

The results also found that there were farmers with low attitudes as many as 3 farmers $(5 \%)$ and farmers with very low attitudes as many as 4 farmers $(6,67 \%)$. Farmers think that the activities have no impact and other sellers still buy their crops at high prices, so they do not feel the need for any activities. This was conveyed by the farmer in the interview as follows "I agree to keep prices stable and build a warehouse to store food reserves but if it is related to stable prices, I disagree because sometimes the price changes" (BK, 60 years).

The farmers' attitude towards the targets of activity based on the cognitive component shows a very high attitude as many as 54 farmers $(90 \%)$, the affective component is classified as very high as many as 56 farmers $(93,33 \%)$, and the conative component is classified as very high as many as 51 farmers $(85 \%)$. Farmers know the targets of P-LDPM and PUPM activities through extension, training, mentoring, and other meetings. Farmers agreed with the target of the activities because they felt that increasing the ability of rice farming would benefit rice farming income. The implementation is that farmers try to improve rice cultivation up to post-harvest so that they get quality grain. This has an impact on the selling price of grain where there is a price difference of IDR 200.00 higher and indirectly affects the stable price of grain. Farmers also feel that Gapoktan activities can provide food reserves and farmers have used 
the food reserves owned by Gapoktan through a loan mechanism and return them at harvest time.

The farmers' attitude in the implementation of the activity in terms of the cognitive component was classified as very high as many as 37 farmers $(61,67 \%)$, the affective component was very high as many as 41 farmers $(81,67 \%)$, and the conative component was very high as many as 42 farmers $(70 \%)$. Farmers know, agree, and are willing to be involved in Gapoktan activities. This is measured from several activities such as regular meetings of the member. Farmers Group Association (Gapoktan) providing knowledge and understanding of the required quality of unhulled rice and rice. The results of the interview also explained that "I strongly agree if it is carried out in order to maintain price stability and also provide food reserves for farmers by providing loans for unhulled rice to farmers in need" (MSF, 50 years). Farmers know that Gapoktan partners with buyers from outside Tanjungsari Village through buying or selling unhulled rice in Gapoktan. Farmers know, agree, and are willing to be involved in the annual member meeting activities of the Farmers Group Association every year.

The farmers' attitude on the benefits of the activity in terms of the cognitive component was classified as very high as many as 42 farmers $(70 \%)$, the affective component was very high as many as 46 farmers $(76,67 \%)$, and the conative component was very high as many as 38 farmers $(63,33 \%)$. The purchase of unhulled rice or rice by the Farmers Group Association (Gapoktan) is interpreted and agreed upon by the farmers as an effort to protect farmers against fluctuations in the price of grain or rice during harvest season or famine season. Farmers in carrying out rice farming know and support the use of facilities owned by Gapoktan such as tractors and Rice Milling Unit (RMU) with mutually agreed procedures. "Gapoktan activities are perceived by farmers, especially regarding the use of infrastructure for the benefit of farmers and there are procedures for leasing" (BK, 60 years).

The cognitive component is a description of one's knowledge about an object of attitude (Azwar, 2009). The cognitive component in this research is farmers' knowledge about the objectives, targets, implementation, and benefits of PLDPM and PUPM activities. The affective component is a form of one's feelings or emotions towards the object of the attitude (Simanjuntak et al, 2014). The affective component is feeling, the agreement of farmer members of Enggal Maju Farmers Group Association regarding the activities carried out by Gapoktan. Attitude seen from the conative component is one's tendency to behave towards the object of attitude (Azwar, 2009). The very high attitude of farmers shows that they understand, agree, and tend to be involved in Gapoktan activities.

Table 2. Multiple Linear Regression Analysis

\begin{tabular}{crrrrl}
\hline & \multicolumn{3}{c}{ Unstandardized Coefficients } & Standardized Coefficients & \\
\cline { 2 - 4 } Model & $\alpha$ & \multicolumn{1}{c}{$\mathrm{b}$} & Std. Error & Beta & Sig. \\
\hline (Constant) & 38,20 & & 14,65 & & 1,01 \\
X1 & & 2,04 & 1,99 & 0,11 & 0,31 \\
X2 & & 4,69 & 1,73 & 0,26 & $0,01^{*}$ \\
X3 & 3,04 & 1,09 & 0,28 & $0,01^{*}$ \\
X4 & 2,02 & 1,76 & 0,12 & 0,25 \\
X5 & $-0,30$ & 1,16 & $-0,03$ & 0,80 \\
X6 & 3,21 & 0,48 & 0,64 & $0,00^{*}$ \\
\hline
\end{tabular}

*) significance at the level $\alpha=5 \%$

Source: Primary Data, 2020 
Attitude is one of the determinants of the active role of farmers in Gapoktan so that it is an important asset for the sustainability of activities.

\section{Analysis of Factors that affect the Farmers' Attitudes in the Food Security Empowerment Program \\ Classical Assumption Test}

The normality test was conducted using the Kolmogorov Smirnov test with a significance level of 0,05 . The test results show the probability value of 0,82 is greater than the significance value of 0,05 . Therefore, it can be concluded that the data is normally distributed. The heteroscedasticity test was conducted using the Glejser test method at a significance level of 0,05 . The test results show that the six independent variables have their respective significance values, namely $\mathrm{X} 1=0,50, \mathrm{X} 2=0,92, \quad \mathrm{X} 3=0,30, \mathrm{X} 4=0,10$, $\mathrm{X} 5=0,43$, and $\mathrm{X} 6=0,06$. It can be concluded that there is no heteroscedasticity. The multicollinearity test is determined by looking at the Variance Inflation Factor and tolerance values. If the VIF value is $<10$ or tolerance $>0,1$ then there is no multicollinearity between the independent variables. The test results show that the VIF value of $X 1=1,37$, $\mathrm{X} 2=1,10, \mathrm{X} 3=1,21, \mathrm{X} 4=1,32, \mathrm{X} 5=1,26$, $\mathrm{X} 6=1,10$ and the tolerance value of $\mathrm{X} 1=$ $0,73, \mathrm{X} 2=0,90, \mathrm{X} 3=0,82, \mathrm{X} 4=0,76, \mathrm{X} 5=$ $0,80, \mathrm{X} 6=0,90$ and therefore multicollinearity does not occur. The linearity test at SPSS uses the test for linearity at a significant level of 0,05 . The test results show that the value of Sig. Deviation from linearity between variables $\mathrm{X}$ and $\mathrm{Y}$ is $0,47,0,98,0,22,0,81$, 0,32 , and 0,34 . Therefore, all independent variables are linear to the dependent variable.

\section{Multiple Linear Regression Analysis}

Based on the data analysis in Table 2, the multiple linear regression equation is obtained as follows:

$$
\begin{gathered}
\mathrm{Y}=38,20+2,04 \mathrm{X} 1+4,69 \mathrm{X} 2+3,04 \mathrm{X} 3+ \\
2,02 \mathrm{X} 4-0,30 \mathrm{X} 5+3,21 \mathrm{X} 6 .
\end{gathered}
$$

Information:

$\mathrm{Y}=$ Attitude

$\mathrm{X} 1=$ Age

$\mathrm{X} 2=$ Land area

$\mathrm{X} 3=$ Personal experience

$\mathrm{X} 4=$ Formal education

$\mathrm{X} 5=$ Non formal education

X6 $=$ The influence of others who are considered important

\section{Hypothesis Testing}

The F test is explained by looking at the $F$ count value or the significance value (sig) at the specified alpha value $(0,05)$. The results of the $\mathrm{F}$ test show that the $\mathrm{F}$ count value of 11,44 is greater than the $F$ table of 2,28 and the significance (sig) of $0,00<$ alpha 0,05. The test results show that the independent variables jointly influence the farmers' attitude.

The objective of the t-test in this study is to determine the influence of each independent variable on farmers' attitudes. The independent variable affects the farmers' attitude if it has a value of $t$ count $>t$ table $(2,005)$ and the significance value ( $\mathrm{sig})<$ alpha 0,05 . The test results showed that three independent variables influenced the farmer's attitude, including (1) arable land area with $t$ count of 2,71 and sig value of 0,01 , (2) personal experience with t count of 2,79 and a sig value of 0,01 , and (3) the influence of other people who are considered important with $t$ count of 6,74 and sig value of 0,00 .

\section{The Coefficient of Determination $\left(\mathrm{R}^{2}\right)$}

The Coefficient of Determination $\left(\mathrm{R}^{2}\right)$ test aims to determine the ability of the independent variables to explain the dependent variable. The results of the analysis obtained an Adjusted R Square value of 0,52. This means the independent variable can explain the diversity of the dependent variable by $52 \%$. While the remaining $48 \%$ is explained by other variables outside the variables used in the study such as the habits or culture of farmers or society. 


\section{Factors Affecting the Attitude of Farmers Age of Farmers}

The t-test for the age of farmers shows a significance value of 0,31 which is greater than the alpha of 0,05 and the $t$ count value of 1,03 is smaller than the value of the table $(2,005)$. This means that the age of the farmer does not affect the farmers' attitude. Farmers in this study are classified as productive age so that they can bring up the same attitude in the P-LDPM and PUPM activities. Farmers of productive age have the same attitude in carrying out rice farming because they are supported by the healthy physical condition, thoughts and ideas to increase the quantity and quality of rice production and increase the income of rice farming. The research results by Susanti et al (2016) state that the productive age of farmers has an effect on ideas, innovations, and thoughts in the success of carrying out their farming.

\section{Arable Land Area}

The results of the t-test for the arable land area show a significance value of 0,01 smaller than alpha 0,05 and the $t$ count value of 2,71 is greater than the value of the $t$ table $(2,005)$. This means that the area of land cultivated by farmers affects farmers' attitudes. The wider the land that is cultivated by farmers, the more positive attitude the farmers have in P-LDPM and PUPM activities. According to Sasongko et al (2014) that the wider the land that is cultivated by farmers, the more positive attitude the farmers have in carrying out farming activities. This is also revealed by Karki et al (2011) that farmers with a large amount of land ownership have a positive attitude and influence their decisions to carry out farming activities. Farmers with large areas of land have innovations and are more effective in carrying out their farming activities than farmers in narrow areas of land who are more careful and skeptical in developing farming activities such as the use of cultivation and post-harvest technology (Oluwasusi, 2014). Farmers in research sites show that farmers with small areas of land are more careful in carrying out their farming activities for fear of failure. Farmers with large areas of land also have more free time, because the yields of their farming are sufficient for their needs, so they support and participate actively in Gapoktan activities. According to Kurniawan and Prihtanti (2018), it is possible for farmers who have a high level of income to be actively involved in activities because they have free time and they do not have the burden to fulfill their own needs and their families by doing work outside of their profession as farmers.

\section{Personal Experience of Farmers}

The t-test of personal experience shows a significance value of 0,01 smaller than alpha 0,05 and the $t$ count value of 2,79 is greater than the $t$ table value $(2,005)$. This means that the farmers' personal experience affects the farmers' attitude. The greater the personal experience of farmers, the more it affects their attitudes on P-LDPM and PUPM activities. The data shows that the average respondent $(91,7 \%)$ has been farming for over 10 years and therefore they have good knowledge and experience in carrying out their farming activities. As Fadhilah et al (2018) stated that the high attitude of rice farmers in implementing the agribusiness system in Cimanggu Cilacap Sub-district is influenced by the experiences of farmers in farming. The personal experience of farmers seen from their involvement and activeness in farmer groups also affects farmers' attitudes. According to Oluwasusi (2014), farmers who are actively involved in group activities have a positive attitude because they get more access to information and can exchange ideas and innovations in farming. Farmers with long personal experiences have good attitudes towards P-LDPM and PUPM activities.

\section{Formal Education}

The results of the t-test for formal education show a significance value of 0,25 greater than alpha 0,05 and the $t$ count value of 1,15 is smaller than the value of the table $(2,005)$. The t-test result means that formal education does not affect farmers' attitudes. 
Farmers generally have the same knowledge, feelings, and tendencies in Gapoktan activities. This is because farmers at various levels of education are members of farmer groups so that knowledge transfer occurs through group activities. The transfer of information between farmers also affects farmers' attitudes. Communication between farmers works well because several things, such as the location of the farmers' rice fields are on the same stretch so that the intensity of the meeting is higher. Information on rice fields was obtained at the time of the interview, namely "in the village of Tanjungsari, the rice fields in one group were on one stretch. Three groups are in a basin area and there is plenty of water, while the other group is in addition to rice fields are in a dry area" (ES, 44 years).

Transfer of information is also easier with the habit of village communities to communicate directly and personally. The existence of communal events in the environment of the farmers such as social gathering, kendurenan (expression of gratitude to God), celebration, and recitation. Therefore, there are no limitations on the interaction between farmers. As the result of the interview with the farmer, "the meeting of extension agents and farmer groups is combined. Group leaders also sometimes deliver information by inserting them during kenduren events, yasinan (recitation), and extension agents are also invited to farmer group events to explain the program" (HEB, 39 years). According to Mardikanto (2010) in principle, communication is a process of interaction between two parties (two farmers) or more in which there is the delivery of information, ideas, or notion. In the context of P-LDPM and PUMP activities, communication between farmers works well to exchange knowledge, feelings, and ideas so that they contribute to farmers' attitudes.

\section{Non Formal Education}

The results of the t-test for the nonformal education variable showed a significance value of 0,80 greater than alpha
0,05 and the $t$ count value of $-0,26$ smaller than the t-table value (2.005). This means that non-formal education does not affect farmers' attitudes. This study indicates that extension, training, and mentoring activities have not been going well $(76,7 \%$ of respondents rarely attend). "Farmers who do not attend meetings usually have other events, they are less concerned about routine activities, farmers will be more enthusiastic if the meeting is related to assistance programs" (HEB, 39 years). This is a form of the dynamic of farmer groups in running the organization. The dynamics of the farmer groups can be seen from the cohesiveness and atmosphere of the group. This also happened to Enggal Maju Farmers Group Association (Gapoktan) where there was dynamism in its activities. According to Rimbawati et al (2018) group cohesiveness is when farmer groups are united based on mutual agreement of all group members. Meanwhile, the group atmosphere is a moral condition, an attitude in the form of a feeling to be involved or passive in the group. Extension, mentoring, and training activities are also carried out in large areas of agriculture, especially after the activity stages are completed so that there is a perception of farmers that the P-LDPM and PUPM activities have been completed and do not continue. According to Euriga (2018), farmers will attend extension services if they receive programs from the government. They have lack enthusiasm when the program stages are completed

\section{The Influence of Others who are Considered Important}

The results of the t-test for the influence of others who are considered important variables show a significance value of 0,00 smaller than alpha 0,05 and the $t$ count value of 6,74 greater than the table value $(2,005)$. The test results can be concluded that the influence of others who are considered important affects farmers' attitudes on P-LDPM and PUPM activities.

Extension agents play a role in mentoring, providing knowledge and skills at 
the stages of farming activities. Assistance in planning the planting activities, extension on rice cultivation, post-harvest management, financial management assistance, administration, and daily routine reports. As the result of the interview, "BPP is an extension of the Department of Agriculture and Food Security and is also as a mentor or representative who is appointed and assigned by the agency so that there is coordination and duties carried out. When the activity stage is carried out every month, the extension agents as mentor report on the progress of activities such as buying and selling of unhulled rice and rice" (PWO, 57 years). According to Arbi dan Sriati (2017), the role of Field Agricultural Extension Agents (PPL) as a mentor to P-LDPM activities is carried out on Farmers Group Association (Gapoktan) and the members of farmers. The role of extension agents is not only limited to delivering innovations and new knowledge but also as an intermediary between farmers and the government or community institutions in relation to innovations or policies made and vice versa (Mardikanto dan Soebianto, 2017).

The role of the Department of Agriculture and Food Security is to carry out education of activities, assistance in planning activities, implementation of activities, and monitoring and evaluation of P-LDPM and PUPM activities. The education of P-LDPM activities was attended by Gapoktan administrators and group representatives. While PUPM activities were represented by Gapoktan officials. The planning stage for PLDPM activities is explained about the construction of Gapoktan warehouses, procurement of food reserves, and plans for utilizing business capital. In PUPM activities, input is given regarding the targets of activity (absorption of unhulled rice grains or rice from farmers and rolling out business capital). The activity implementation stage is mentoring in the process of purchasing grain or rice, distribution, and food reserves (specifically for P-LDPM activities). Monitoring and evaluation are to coordinate the reporting of development activities of purchasing, distribution, and food reserves (specifically for P-LDPM activities).

The role of the Head of Farmers Group Association is crucial because it is in charge of coordinating with various parties such as the Department of Agriculture and Food Security, the Agricultural Extension Center, the Village Government, and partners of Farmers Group Association (Gapoktan). The Head of Gapoktan is the coordinator of Gapoktan management. According to Mutmainah and Sumardjo (2014), group leaders play a crucial role in directing members, facilitating the achievement of group goals, dynamist of member activeness, and accommodating members' aspirations. This was delivered by the Head of Enggal Maju Farmers Group Association during an interview, namely "managing farmers is not an easy process, given work background and knowledge. Farmers are enthusiastic about this activity. Moreover, there is a price difference, then there are subsidies for drying, milling, and there are food reserves that can be borrowed when needed. However, some still do not understand. As if they are looking for profit, are used by a group of people, and are not transparent. In principle, the activities are carried out following existing instructions" (Myf, 48 years).

The management of the Farmers Group Association is not entirely active in the activities because some feel they can carry out farming activities by themselves. Thus, it can be used as evaluation material because the role of the Head of Farmers Group Association is becoming more dominant. Syahyuti (2012) explains that in farmer institutions there is a term of organizational individualization, namely farmer institutions that have a complete organizational structure but in practice, only certain people or leaders carry out organizational functions. The organization runs simple, limited, and in theory, the organization is in weak condition. 
Food Security Empowerment Program

The objective of the empowerment of farmers in P-LDPM activities is to stabilize food prices, distribution, and food reserves. Farmers Group Association (Gapoktan) received these activities in 2011. Social assistance funds are the initial capital for developing activities and can be managed properly. One of the assessments of the sustainability of the activity is that in 2018 Enggal Maju Farmers Group Association (Gapoktan) received the Adhikarya Pangan Nusantara award at the Central Java Province level for the category of food distribution actors.

P-LDPM activities are carried out by purchasing farmers' crops and distributing them to related partners. The purchase price of grain or rice to farmers follows price developments and Gapoktan always provides a price difference above the average price in the market. "We buy unhulled rice or rice from farmers by looking at the market price and usually give a difference of IDR 75.00 100.00 per kilogram higher on the condition that the unhulled rice or rice is in accordance with the requirements" (Bwo, 30 years). Farmers generally sell unhulled rice in the form of milled dry unhulled rice (GKG). The purchase of unhulled rice or rice comes from the members of farmers of Gapoktan and partners of Farmers Group Association (Gapoktan) outside Tanjungsari Village. "When the program stages were implemented, the procurement of unhulled rice from members of farmers of Gapoktan reached 80 percent. Today, 50 percent of the purchase of unhulled rice or rice comes from members of farmers and 50 percent from outside the region" (Bwo, 30 years).

Gapoktan has food reserves that are distributed to farmers. The initial fund of 20 million is used to buy 4 tons of milled dry unhulled rice $(\mathrm{GKG})$. Farmers can borrow unhulled rice if they need to meet their daily food needs with a maximum loan of 3 quintals. Gapoktan and farmers agree that the farmers can return unhulled rice by providing services to Gapoktan for operation and maintenance of $10 \mathrm{~kg}$ for every 1 quintal of unhulled rice borrowed. Currently, the food reserve fund has grown to around 31,7 million. If the food reserve is not used, it will be rejuvenated by selling the rice reserves and replacing them with a new one.

$$
\text { Enggal Maju Farmers Group }
$$

Association (Gapoktan) received PUPM activities in 2017 on the basis that they have a good assessment from the Department of Agriculture and Food Security of Kebumen Regency on the implementation of the PLDPM program. PUPM activities have similarities with the P-LDPM program. The difference is that there is no food reserve fund. The function of food reserves is to report the available stock at Gapoktan for rice supply and Indonesian Farmers' Shops (TTI) as merchants to consumers. The distribution of rice is carried out to the appointed partners of Gapoktan, namely TTI and is located in non-rice center areas. All these needs have been fulfilled by farmers in Tanjungsari Village. In stages, PUPM activities have been completed in 2019 and therefore there is no obligation to supply. However, based on interviews, Gapoktan still supplies rice to the partners of PUPM activities. "We were asked to continue supplying rice by shops that have been partners with PUPM activities because we already have a good relationship and can deliver rice properly" (Myf, 48 years). The price of rice is determined based on the mutual agreement according to price developments during the distribution of rice.

The results showed that in one planting season, Gapoktan can only absorb farmers' grain about $15-20$ percent of the total potential grain production of the members of Enggal Maju Farmers Group Association. Several things that underlie farmers not selling unhulled rice to Farmers Group Association include (1) farmers' habit of storing unhulled rice. They do not directly sell their crops. They sell unhulled rice when they need them and previously they have left about 30 percent for their daily food needs; (2) farmers sell unhulled rice to other collectors because they are tied to a capital loan for rice 
cultivation. Therefore, during the harvest time they have to sell it to collectors; (3) farmers have a narrow area of land so that it is only sufficient to meet daily food needs; and (4) harvested unhulled rice is stored and sold to other collectors when farmers in urgent need.

Farmers Group Association serves to distribute food through the development of buying and selling partners. The partnership developed takes into account the benefits of the Farmers Group Association and its members, such as receiving rice produced by farmers in Tanjungsari Village. Farmers Group Association has collaborated with various parties, including The National Food Logistics Agency (BULOG), trade kiosks in Purworejo, Wonosobo, Kulonprogo, Sleman, Cilacap, Ciamis, and e-warong on the NonCash Food Assistance (BPNT) program in Kebumen. Gapoktan is initiating a partnership with two parties, namely: (1) as a supplier of unhulled rice to the Integrated Rice Processing Center (SPBT) which is a program of the Ministry of State-Owned Enterprises (BUMN) through PT. Bank Mandiri and Pertamina, which are planned to operate in 2021, and (2) observation or survey with the Regional Government of Kebumen Regency in meeting the needs of the Kebumen Regency civil state apparatus (ASN).

\section{CONCLUSIONS}

The farmers' attitude in the food security empowerment program (P-LDPM and PUPM) in terms of cognitive, affective, and conative components on the objective of activities, targets of activity, implementation of the activity, and benefits of the activity are classified as very high. Age of farmers, arable land area, personal experience, formal education, non-formal education, and the influence of others who are considered important collectively have a significant effect on farmers' attitudes. Partially, arable land area, personal experience, and the influence of others who are considered important have a significant effect on farmers' attitudes in the food security empowerment program (P-LDPM and PUPM).

Sustainable empowerment through extension, training and mentoring is crucial to improve the quality and sustainability of PLDPM and PUPM activities. Farmers Group Association (Gapoktan) should be able to maximize management, increase the volume of food reserves, strengthen existing partnerships, and strengthen coordination with related institutions or agencies. The very high attitude of farmers is an important asset for Farmers Group Association (Gapoktan) to increase their active role in activities. Strengthening non-formal education through extension media, training, and mentoring so that farmers actively involve in Gapoktan activities.

\section{REFERENCES}

Alif, M. 2017. Partisipasi petani dalam komunikasi penyuluhan. Meta Communication: Journal of Communication Studies 2(2): 155-168.

Arbi, M. and Sriati. 2017. Analisis kinerja penyuluh pertanian lapangan dalam program lembaga distribusi pangan masyarakat di Kecamatan Makarti Jaya Kabupaten Banyuasin Sumatera Selatan. Jurnal Penyuluhan 13(2): 125132.

Azwar, S. 2009. Sikap Manusia Teori dan Pengukurannya (2nd ed.). Yogyakarta. Pustaka Pelajar.

Azwar, P. Muljono, and T. Herawati. 2016. Persepsi dan partisipasi petani dalam pelaksanaan rehabilitasi tanaman kakao di Kabupaten Sigi Provinsi Sulawesi Tengah. Jurnal Penyuluhan 12(2): 157-167.

Badan Ketahanan Pangan. 2015. Laporan pelaksanan analisis kelembagaan distribusi pangan tahun 2015. Badan Ketahanan Pangan Kementerian Pertanian. Jakarta. 
Badan Pusat Statistik. 2018a. Kajian konsumsi bahan pokok 2017. Jakarta: Badan Pusat Statistik.

Badan Pusat Statistik. 2018b. Proyeksi penduduk Indonesia 2015-2045. Jakarta: Badan Pusat Statistik.

Badan Pusat Statistik. 2019a. Berita resmi statistik keadaan ketenagakerjaan Indonesia Agustus 2019. Jakarta: Badan Pusat Statistik.

Badan Pusat Statistik. 2019b. Berita resmi statistik luas panen dan produksi padi di Indonesia tahun 2019. Jakarta: Badan Pusat Statistik.

Badan Pusat Statistik. 2019c. Statistik pemuda Indonesia 2019. Jakarta: Badan Pusat Statistik.

Badan Pusat Statistik Provinsi Jawa Tengah. 2018a. Hasil survei pertanian antar sensus 2018 Provinsi Jawa Tengah. Semarang: Badan Pusat Statistik Provinsi Jawa Tengah.

Badan Pusat Statistik Provinsi Jawa Tengah. 2018b. Statistik pemuda Provinsi Jawa Tengah 2018. Semarang: Badan Pusat Statistik Provinsi Jawa Tengah.

Creswell, J. W. 2018. Research design, pendekatan metode kualitatif, kuantitatif, dan campuran (Translated by A. Fawaid and R. K. Pancasari). Yogyakarta: Pustaka Pelajar.

Euriga, E., S. Amanah, A. Fatchiya, and P. S. Asngari. 2018. Implementasi penyuluhan hortikultura berkelanjutan di Provinsi D.I. Yogyakarta. Jurnal Penyuluhan 14(2): 289-307.

Fadhilah, M. L., B. T. Eddy and S. Gayatri. 2018. Pengaruh tingkat pengetahuan, sikap dan keterampilan penerapan sistem agribisnis terhadap produksi pada petani padi di Kecamatan Cimanggu Kabupaten Cilacap. Jurnal Agrisocionomics 2(1): 39-49.

Ghozali, I. 2018. Aplikasi Analisis Multivariat dengan Program IBM
SPSS 25 edisi kesembilan. Semarang. Badan Penerbit Universitas Diponegoro.

Hamyana. 2017. Motif kerja generasi muda di bidang pertanian: Studi fenomenologi tentang motif kerja di bidang pertanian pada kelompok pemuda tani di Kota Batu. Mediapsi 3(1): 34-42.

Ikhsan, P. Muljono, and D. Sadono. 2018. Persepsi petani tentang kompetensi keujruen blang di Kabupaten Aceh Besar Provinsi Aceh. Jurnal Penyuluhan 14(2): 347-361.

Karki, L., R. Schleenbecker, and U. Hamm. 2011. Factors influencing a conversion to organic farming in Nepalese tea farms. Journal of Agriculture and Rural Development in the Tropics and Subtropics (JARTS) 112(2): 113-123.

Kurniawan W. A. and T. M. Prihtanti. 2018. Jenjang partisipasi dan determinan partisipasi petani dalam introduksi budidaya padi organik di Desa Pulutan, Kota Salatiga. Jurnal Penyuluhan 14(2): 199-208.

Mardikanto, T. 2010. Komunikasi Pembangunan. Surakarta. UNS Press.

Mardikanto, T. and P. Soebianto. 2017. Pemberdayaan Masyarakat dalam Perspektif Kebijakan Publik (4th. Ed.). Bandung. Afabeta.

Miles, M. B., A. M. Huberman, and J. Saldana, J. 2014. Qualitative Data Analysis, a Methods Sourcebook (3rd ed.). California. Sage Publications.

Mustangin, D. Kusniawati, N. P. Islami, B. Setyaningrum, B., and E. Prasetyawati. 2017. Pemberdayaan masyarakat berbasis potensi lokal melalui program desa wisata di Desa Bumiaji. Jurnal Sosioglobal 2(1): 59-72. 
Mutmainah, R. and Sumardjo. 2014. Peran kepemimpinan kelompok tani dan efektivitas pemberdayaan petani. Jurnal Sosiologi Pedesaan 2(3): 182199.

Oluwasusi J. O. 2014. Vegetable farmer's attitude toward organic agriculture practices in selected states of South West Nigeria. Journal of Agricultural Extension and Rural Development 6(7): 223-230.

Purnama, B. J., H. Hamidi, and T. Sjah. 2017. Sikap petani tembakau Virginia terhadap program kemitraan PT. Export Leaf Indonesia di pulau Lombok. Jurnal Agrotek Ummat 4(2): 85-93.

Republik Indonesia. 2012. Undang-undang nomor 18 tahun 2012 tentang pangan. Lembaran Negara Republik Indonesia Nomor 227 Tahun 2012. Jakarta: Sekretariat Negara.

Rimbawati, D. E. M., A. Fatchiya, and B. G. Sugihen. 2018. Dinamika kelompok tani hutan agroforestry di Kabupaten Bandung. Jurnal Penyuluhan 14(1): 92-103.

Sarwono, J. 2012. Mengubah data ordinal ke data interval dengan metode suksesif interval (MSI). http://www.jonathansarwono.info/teori spss/msi.pdf. Accessed on 26 September 2019.

Sasongko, W. A., R. Witjaksono, and Harsoyo. 2014. Pengaruh perilaku komunikasi terhadap sikap dan adopsi teknologi budidaya bawang merah di lahan pasir pantai Kecamatan Sanden Kabupaten Bantul. Jurnal Agro Ekonomi 24(1): 35-43.

Simanjuntak, O.V., Subejo, and Witjaksono, R. 2016. Partisipasi petani dalam program gerakan penerapan pengelolaan tanaman terpadu padi di Kecamatan Kalasan Kabupaten Sleman. Agro Ekonomi 27(1): 27-35.
Simanjuntak, S. A., W. Talib, and E. Kernalis. 2014. Sikap petani terhadap penerpan teknologi budidaya kedelai lahan pasang surut (di Kelurahan Simpang Kecamatan Berbak Kabupaten Tanjung Jabung Timur). Jurnal SosioEkonomika Bisnis, 17(1), 28-35.

Siregar, S. 2015. Statistik Parametrik untuk Penelitian Kuantitatif. Jakarta. PT. Bumi Aksara.

Sriati, N. Hakim, and M. Arbi. 2016. Kinerja kelompok tani dalam program lembaga distribusi pangan masyarakat (LDPM) dan hubungannya dengan produksi dan pendapatan petani padi di Kecamatan Makarti Jaya Kabupaten Banyuasin. Jurnal Lahan Suboptimal 5(2): 208-218.

Susanti, D., N. H. Listiana, and T. Widayat. 2016. Pengaruh umur petani, tingkat pendidikan dan luas lahan terhadap hasil produksi tanaman Sembung. Jurnal Tumbuhan Obat Indonesia 9(2): 75-82.

Susilowati, S. H. 2016. Fenomena penuaan petani dan berkurangnya tenaga kerja muda serta implikasinya bagi kebijakan pembangunan pertanian. Forum Penelitian Agro Ekonomi 34(1): 35-55.

Syahyuti. 2012. Pengorganisasian secara personal dan gejala individualisasi organisasi sebagai karakter utama pengorganisasian diri petani di Indonesia. Forum Penelitian Agro Ekonomi 30(2): 129 -145. 